\title{
Performance Analysis of T-type Inverter Based on Improved Hysteresis Current Controller
}

\author{
M. İNCI
}

\begin{abstract}
This paper presents an improved hysteresis current control method for five level T-type inverter. The proposed method is based on four hysteresis levels and performed to generate switching signals of fundamental transistors in T-type inverter. By using generated signals through hysteresis controller, bidirectional switch in T-type inverter is triggered through the logical way. The system is detailed in analytical expression and exhibited to generate five voltage levels at the output of inverter. The improved technique is based on an error signal between the output current and the reference value. Therefore, the proposed modulation technique achieves the following output current at the desired value and ensures highefficiency conversion ratio at the output. In order to show the validity of the proposed method, the controller is compared with conventional sinusoidal pulse width modulated T-type inverter. In performance results, it is obvious that the proposed method provides a lower total harmonic distortion in comparison with conventional method.
\end{abstract}

Index Terms-Hysteresis current controller, T-type inverter, Comparison, Total harmonic distortion, Sinusoidal pulse width modulation.

\section{INTRODUCTION}

$I^{2}$ N INDUSTRIAL APPLICATIONS, inverters are known as power electronic converters which convert dc electrical power into ac electrical power. These converters exist in different implementations such as renewable energy integration, custom power devices, industrial and home appliances in different power ranges $[1,2]$. In order to convert $\mathrm{dc}$ power into ac power, traditional inverters cause high switching losses, electromagnetic interferences and high total harmonic distortion (THD) [3-5]. An alternative solution is the utilization of multilevel inverter to minimize the disadvantages of conventional inverters [6]. Multilevel inverters have highefficiency conversion ratio, low electromagnetic interferences and low power losses in energy conversion implementations compared to conventional inverters [7-9]. Because they have more smooth voltage waveforms with an increased number of

MUSTAFA INCI, is with Department of Mechatronics Engineering, Iskenderun Technical University, Hatay, Turkey, (e-mail: mustafa.inci@iste.edu.tr )

iD https://orcid.org/0000-0002-0900-5946

Manuscript received January 8, 2019; accepted March 26, 2019.

DOI: $10.17694 /$ bajece. 510412 voltage levels compared to classical inverters[10]. Besides, they require low-rated filters thereby diminishing the entire system dimension. These inverters also reduce the THD level at output voltage thus increasing the power quality of the entire system $[11,12]$.

Conventional inverters are generally preferred for low power applications. But, the usage of these inverters becomes difficult to apply owing to the high voltages that the switching devices must block [13-15]. In this case, the solution is to use multilevel inverters. In these conditions, multilevel inverters replace conventional inverters. The most common multilevel inverter topologies are cascaded $\mathrm{H}$-bridge, diode clamped and flying capacitors $[16,17]$. Also, there are several switches reduced multilevel inverter topologies in addition to $\mathrm{H}$-bridge, diode clamped and flying capacitors. Among switch reduced multilevel inverters, T-type inverter is an alternative solution which generates five levels with fewer components [18, 19]. There are different modulation techniques to generate a more smooth output voltage with less THD. Sinusoidal pulse width modulation, space vector modulation, selective harmonic elimination and hysteresis pulse width modulation are common techniques in the literature [20, 21]. However, conventional T-type inverters use conventional sinusoidal based PWM methods in order to convert dc voltage to ac voltage. For this purpose, in this paper, hysteresis-band controller with current feedback is firstly integrated with five level T-type inverter. The study also evaluates the performance of T-type based on hysteresis controller according to THD, efficiency and voltage output. Also, the performance results of hysteresis band controller is compared to spwm.

\section{T-TYPE INVERTER}

Fig. 1 introduces the circuit scheme of a five-level T-type inverter. This structure consists of four mono-directional switches (S1, S2, S3 and S4), one bidirectional switch and two dc sources per phase [22]. The presented bidirectional switch includes two back-back mono-directional switches and triggered simultaneously. For higher voltage levels, topology requires more bidirectional switches and dc voltage sources [23].

To generate five voltage levels by using T-type inverter, two dc-link capacitors (of each $\mathrm{Vdc} / 2$ ) are used per phase. In the operation of the inverter, $\mathrm{S} 1-\mathrm{S} 4$ and $\mathrm{S} 2-\mathrm{S} 3$ are turned on to generate $\mathrm{Vdc}$ and $-\mathrm{Vdc}$ levels, respectively [24]. The switching states to generate all voltage levels are given in Table 1. The equivalent circuits of T-type inverter during 
switching states are introduced in Fig. 2. In the first state, S1 and S4 are turned on and the output voltage is equal to $+\mathrm{Vdc}$. In this state, the operation of T-type inverter is similar to the positive cycle of conventional $\mathrm{H}$-bridge inverter and the current follows the path from $\mathrm{S} 1$ and returns from $\mathrm{S} 4[18,23]$. In State 2, bidirectional switch S5 and S4 are closed and the voltage value is half the dc voltage in positive. The current flows through $\mathrm{C} 2$ and $\mathrm{S} 4$ in order to complete full path. In the third stage, bidirectional switch S5 and S3 are turned on to generate negative half $\mathrm{dc}$ voltage at load [25]. In this condition, the current flows through $\mathrm{C} 1-\mathrm{S} 3-\mathrm{S} 5$ and the direction of current is opposite to state 2. In the fourth stage, $\mathrm{S} 2$ and $\mathrm{S} 3$ are turned on and the output voltage is obtained as the inverse voltage of dc source [26]. This is the negative cycle operation of conventional H-bridge inverter. In state 5 and state 6, S2-S3 and S1-S3 are respectively turned on to obtain zero voltage at the load.
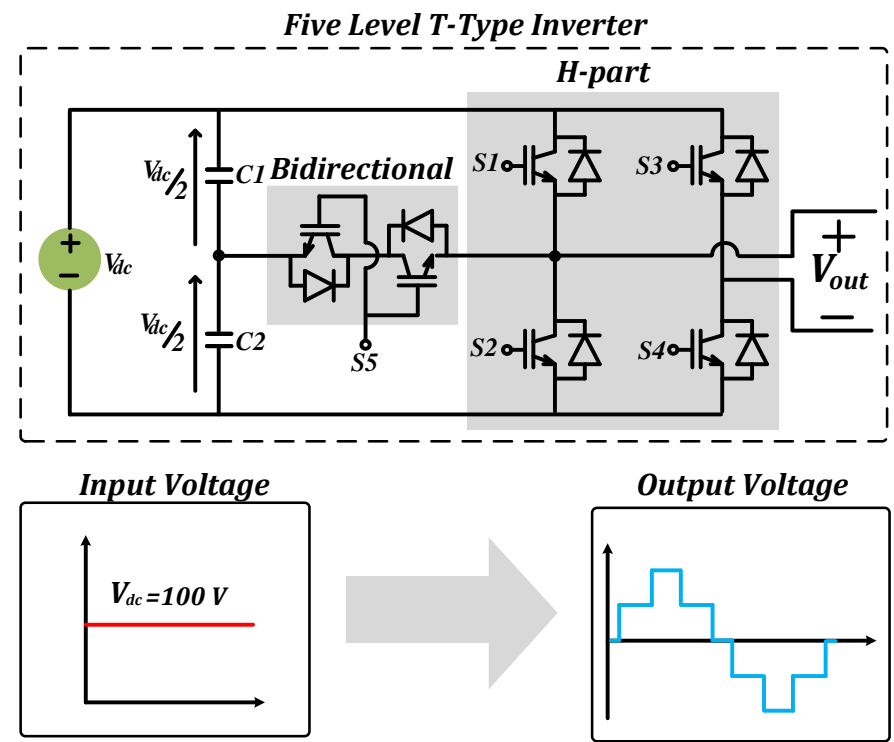

Fig.1. The circuit scheme of five level T-type inverter

TABLE I

THE SWITCHING STATES OF FIVE-LEVEL T-TYPE INVERTER OUTPUT VOLTAGE

\begin{tabular}{cccccc}
\hline S1 & S2 & S3 & S4 & S5 & Vout \\
\hline 1 & 0 & 0 & 1 & 0 & $+\mathrm{Vdc}$ \\
0 & 0 & 0 & 1 & 1 & $+\mathrm{Vdc} / 2$ \\
0 & 0 & 1 & 0 & 1 & $-\mathrm{Vdc} / 2$ \\
0 & 1 & 1 & 0 & 0 & $-\mathrm{Vdc}$ \\
0 & 1 & 0 & 1 & 0 & 0 \\
1 & 0 & 1 & 0 & 0 & 0 \\
\hline
\end{tabular}

For a resistive-inductive load connected T-type inverter, the relationship of voltage and current at load-side is given as [27]:

$$
V_{\text {out }}=R i_{\text {load }}+L \frac{d i_{\text {load }}}{d t}
$$
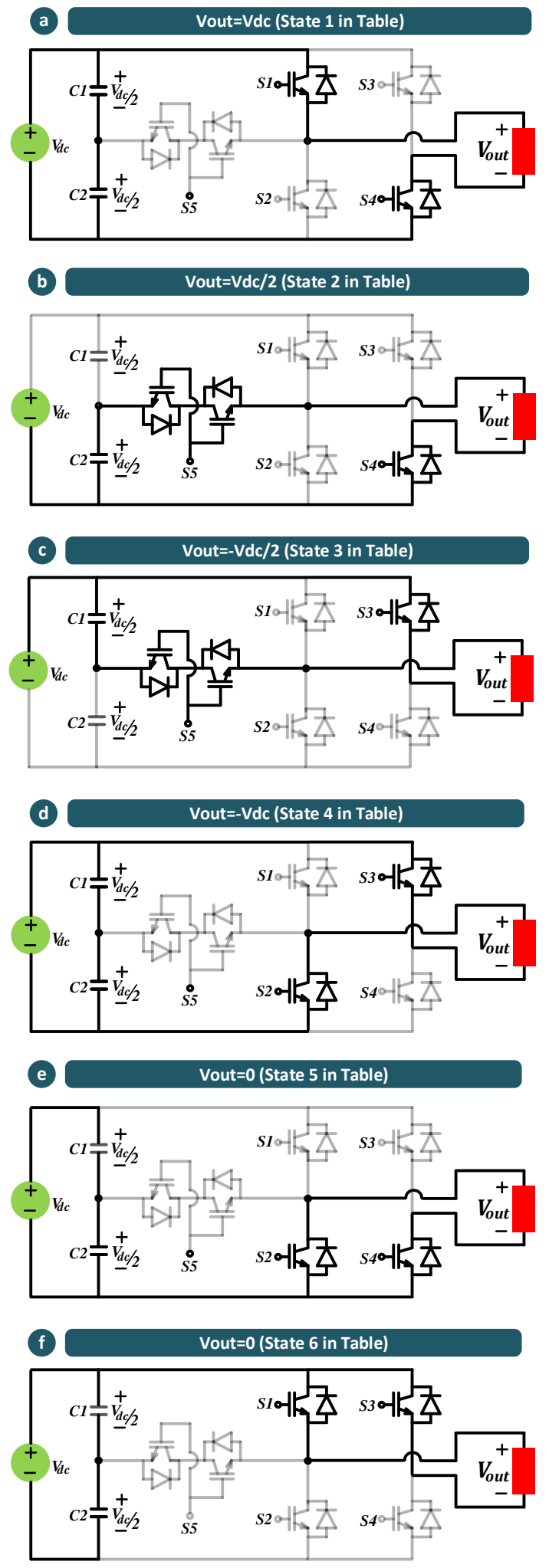

Fig. 2 The switching states and equivalent circuits of T-type inverter 
Rearranging the (1), the equations can be written in the new form:

$$
\begin{gathered}
\Delta i_{\text {load }}=i_{\text {load }}^{*}-i_{\text {load }} \\
V_{\text {out }}=R i_{\text {load }}+L \frac{\Delta i_{\text {load }}}{d t}
\end{gathered}
$$

Assuming the value of resistance is very small, we can write the reference voltage in (4):

$$
V_{\text {ref }}=L \frac{\Delta i_{\text {load }}}{d t}
$$

In the final arrangement, it is clear that the output voltage is controlled by the small change of load current, as introduced in (5) and (6) [27].

$$
\begin{gathered}
L \frac{\Delta i_{\text {load }}}{d t}=L \frac{d i_{\text {load }}^{*}}{d t}-\text { Vout } \\
L \frac{\Delta i_{\text {load }}}{d t}=V_{\text {ref }}-\text { Vout }
\end{gathered}
$$

\section{THE PROPOSED CONTROLLER}

In switching of T-type inverters, spwm based controller methods are used to generate switching signals [28]. However, these methods cannot achieve the following output current at the desired value. For this purpose, in this paper, hysteresisband controller with feedback current is improved and designed for five-level T-type inverter. The hysteresis controller defines the states of the switching devices in an inverter to make current follow its reference value. In the implementation of the hysteresis controller, the switching is accomplished through a maximum error band of current $(\Delta \mathrm{i})$ $[29,30]$. This method is based on instantaneous feedback current control in which the load current permanently tracks the reference current within hysteresis band values [31].

Figure 3 clarifies the working fundamentals of the hysteresis-band controller based on current error. In classical hysteresis band controller, it consists of two hysteresis bands: upper and lower. When the current exceeds upper band, the switching signals are produced and the switch is turned on. If the value of current passes to the lower-band, the switching signal turns off.

In the proposed controller scheme, four hysteresis values are determined, and it is compared with the actual current error signal. When the current exceeds a pre-defined hysteresis band, the switching signals are produced and the switches are turned on or turned off according to a rational rule. The scheme of proposed hysteresis current controlled T-type inverter is introduced in Fig. 4. The expression of the scheme is expressed below.

In T-type inverter, when S1 and S4 are in conduction mode, the slope of current is positive and describe as follows:

$$
\frac{d i}{d t}=\frac{V_{d c}-V_{m} \sin (\omega t+\theta)}{L}
$$

When S5 and S4 are in conduction mode, the slope of current is positive and the output voltage is equal to $+\mathrm{Vdc} / 2$. It is described as:

$$
\frac{d i}{d t}=\frac{V_{d c} / 2-V_{m} \sin (\omega t+\theta)}{L}
$$

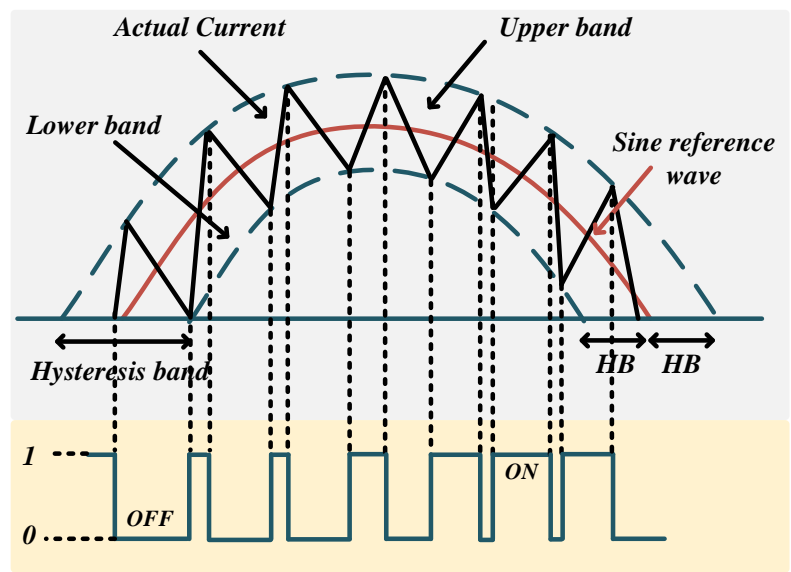

Figure 3. A classical presentation of conventional hysteresis current controller

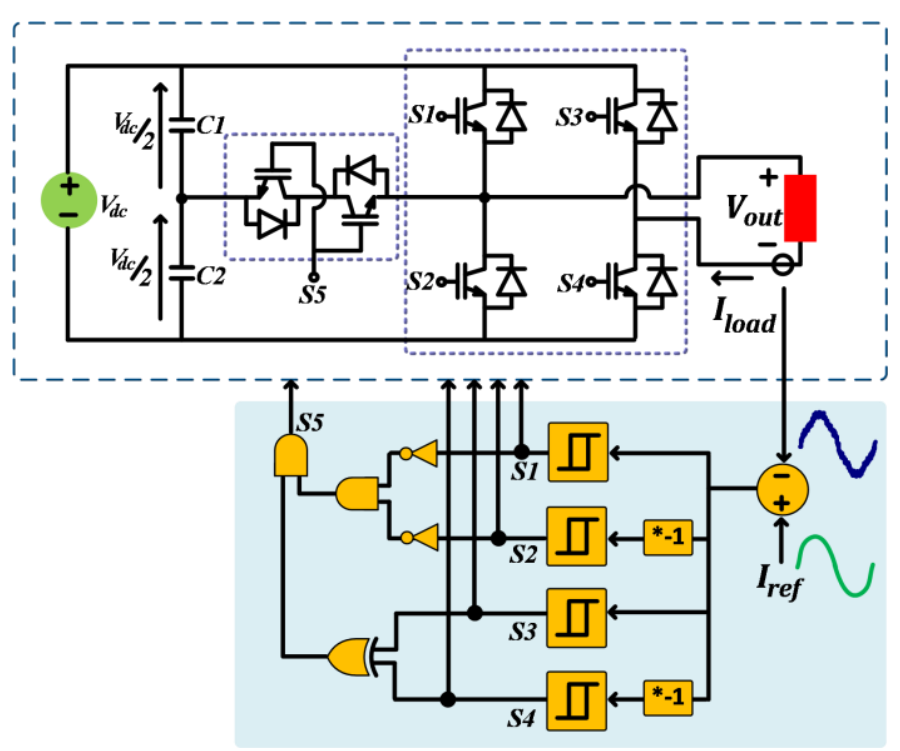

Fig. 4 The proposed hysteresis controller for five-level T-type inverter

In conduction states of S5 and S2, the slope of current is negative and the output voltage is equal to $-\mathrm{Vdc} / 2$. It is described as:

$$
\frac{d i}{d t}=\frac{-\left(V_{d c} / 2+V_{m} \sin (\omega t+\theta)\right)}{L}
$$

In which, $V_{d c}$ is dc input voltage, $V_{m} \sin (\omega t+\theta)$ is instantaneous load voltage and $L$ is inductance value. The similar relation when the $\mathrm{S} 2-\mathrm{S} 3$ is turned on and it is written as follows:

$$
\frac{d i}{d t}=\frac{-\left(V_{d c}+V_{m} \sin (\omega t+\theta)\right)}{L}
$$

In hysteresis-controller, current ripples and switching frequency are dependent on the depth of the band. For instance, switching at high frequency and low ripple is obtained by very small band value. Also, an optimal band that provides stabilization between harmonics ripples and switching losses is fascinating. Figure 5 presents the illustration of hysteresis band modulation technique for five- 
level T-type inverter. In the controller, the error signal is applied at the input of comparator with hysteresis bands.

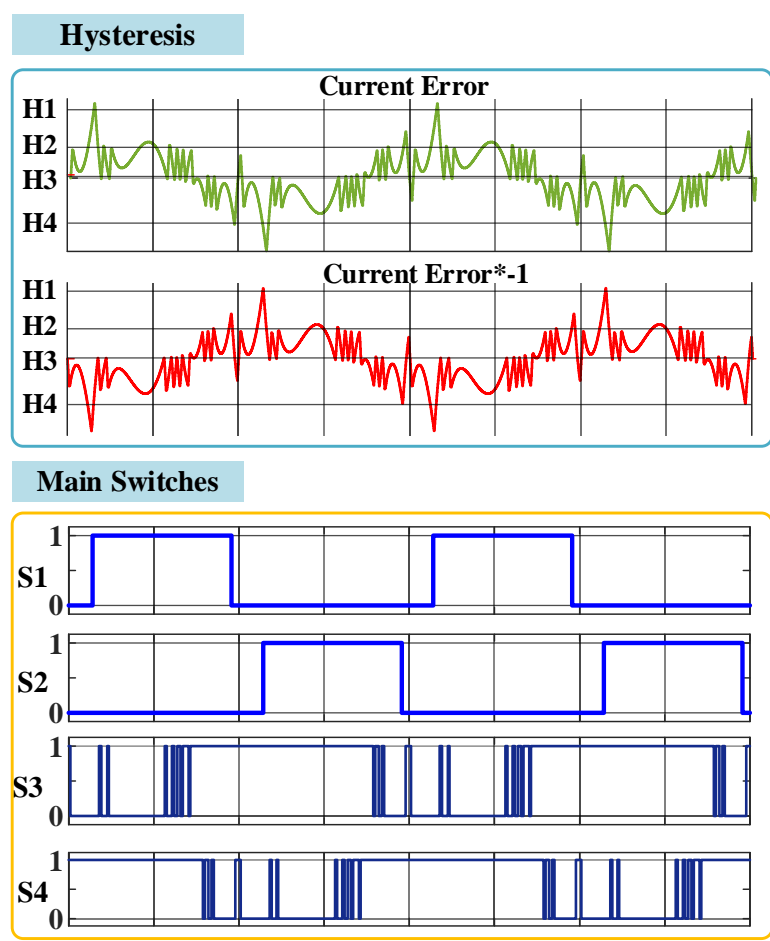

Bidirectional S

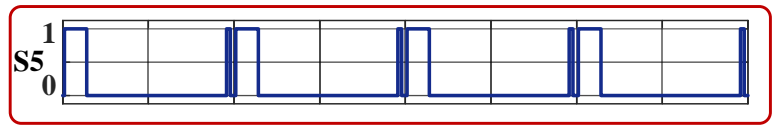

Output Voltage

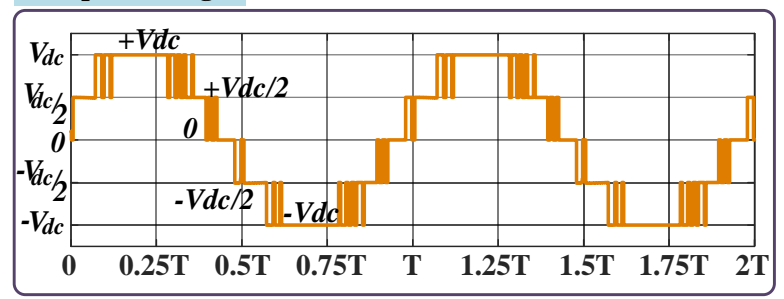

Fig. 5 Illustration of improved hysteresis-band current control based T-type inverter

According to the hysteresis rule of T-type inverter, the conditions for $\mathrm{S} 1, \mathrm{~S} 2, \mathrm{~S} 3$ and $\mathrm{S} 4$ are:

The switching states of $\mathrm{S} 1$ are given as:

$$
S_{1}=\left(\begin{array}{c}
i_{\text {load }}^{*}-i_{\text {load }}>H 1 \rightarrow \text { ON } \\
i_{\text {load }}^{*}-i_{\text {load }}<H 4 \rightarrow \text { OFF }
\end{array}\right)
$$

The switching states of S2 are expressed as:

$$
S_{2}=\left(\begin{array}{c}
i_{\text {load }}^{*}-i_{\text {load }}<H 1 \rightarrow \text { ON } \\
i_{\text {load }}^{*}-i_{\text {load }}>H 4 \rightarrow \text { OFF }
\end{array}\right)
$$

The switching states of S3 are defined as:

$$
S_{3}=\left(\begin{array}{c}
i_{\text {load }}^{*}-i_{\text {load }}>H 2 \rightarrow \text { ON } \\
i_{\text {load }}^{*}-i_{\text {load }}<H 3 \rightarrow O F F
\end{array}\right)
$$

The switching states of S4 are defined as:

$$
S_{4}=\left(\begin{array}{c}
i_{\text {load }}^{*}-i_{\text {load }}<H 2 \rightarrow \text { ON } \\
i_{\text {load }}^{*}-i_{\text {load }}>H 3 \rightarrow \text { OFF }
\end{array}\right)
$$

where $\mathrm{H} 1, \mathrm{H} 2, \mathrm{H} 3$ and $\mathrm{H} 4$ define the levels of hysteresis controller.

The switching of bidirectional S5 is achieved by logical gates according to the logic table. The switch is turned-on or turned-off according to the below rule:

$$
S 5=\overline{S 1} \cdot \overline{S 2} \cdot(S 3 \overline{S 4}+\overline{S 3} S 4)
$$

Bidirectional (S5) signal is derived according to the karnaugh-map rule by using Table 1 .

\section{PERformance Results}

The proposed modulation strategy is modeled and tested in the Simulink environment. In the tested system, one bidirectional and four mono-directional switches are triggered to generate the output voltage. For this purpose, $100 \mathrm{~V} \mathrm{dc}$ voltage is used at the input of inverter and $3 \mathrm{ohm}$ resistor is used as a load. Performance results are obtained with and without output filter. The system parameters of the designed model is given in Table 2 .

TABLE II

THE SYSTEM PARAMETERS OF THE DESIGNED CIRCUIT

\begin{tabular}{lr}
\hline System parameters & Value \\
\hline Input voltage & $100 \mathrm{Vdc}$ \\
Output voltage frequency & $50 \mathrm{~Hz}$ \\
Transistor & $\mathrm{MOSFET}$ \\
Number of transistors & $\mathrm{Six}(6)$ \\
DC-link capacitors & $100 \mathrm{uF}$ \\
Load resistor & $2 \mathrm{ohm}$ \\
Load inductor & $2.2 \mathrm{mH}$ \\
Filter & $\mathrm{Lf}=1 \mathrm{mH} \mathrm{Lc=1 \textrm {uF }}$ \\
\hline
\end{tabular}

In the performance stage, hysteresis current controller is performed for two conditions of hysteresis bands. Also, a performance comparison is given in order to show the effectiveness of the proposed method. In the first case study, the hysteresis bands are selected in a wide range. The values of hysteresis are $0.8,0.3,0$ and -0.5 for $\mathrm{H} 1, \mathrm{H} 2, \mathrm{H} 3$ and $\mathrm{H} 4$, respectively. By this way, the waveforms of switching states and output voltage are introduced in Fig. 6. It is clear that Ttype inverter generate five voltage levels through a proposed hysteresis current controller method. 


\section{Proposed method based on wide bands}
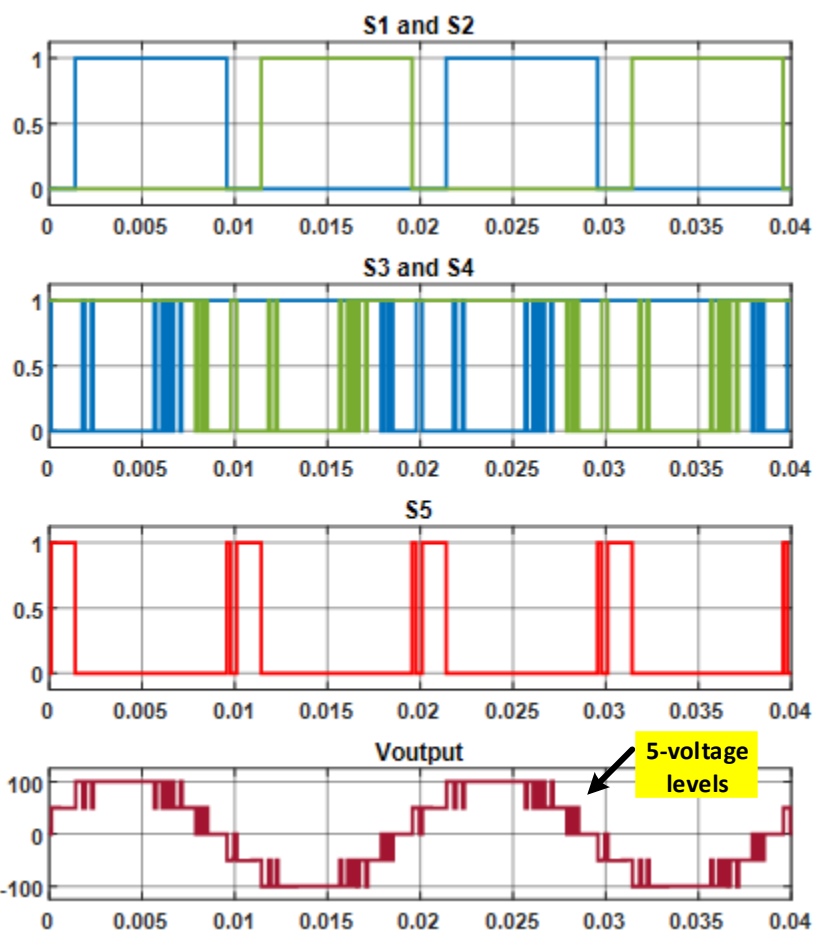

Fig. 6 Switching signals and output voltage at wide-range hysteresis band

In the second case study, T-type inverter with control based on Hysteresis control is performed in narrowband values. The values of hysteresis bands are respectively $0.8,0.3,0$ and -0.5 for $\mathrm{H} 1, \mathrm{H} 2, \mathrm{H} 3$ and $\mathrm{H} 4$. In this state, the frequency of the narrowest switching pulse is measured as $10 \mathrm{kHz}$. The switching states and square-wave output voltage waveforms are presented in Figure 7. It is obvious that the switching frequency of the inverter is higher in comparison of first case.

When the LC filter is used at the output of the inverter, the voltage and current filtered become in sinusoidal form. The waveforms of voltage and current after the filtering are presented in Figure 8. In this case, the performance results are taken for narrowband based hysteresis current controller method.

In performance assessment, THD values of spwm and proposed hysteresis current controller are compared. The harmonic spectrums of both spwm and the proposed method are given in Figure 9. It presents individual harmonic components up to $1 \mathrm{kHz}$. The switching frequency of each method is selected as $10 \mathrm{kHz}$ for comparison. The comparison results show that THD value by using conventional spwm is 2.97 percent. However, the proposed method can achieve to reduce lower THD values. THD value by using the proposed method is shown as 1.21 percent.

\section{Proposed method based on narrow bands}
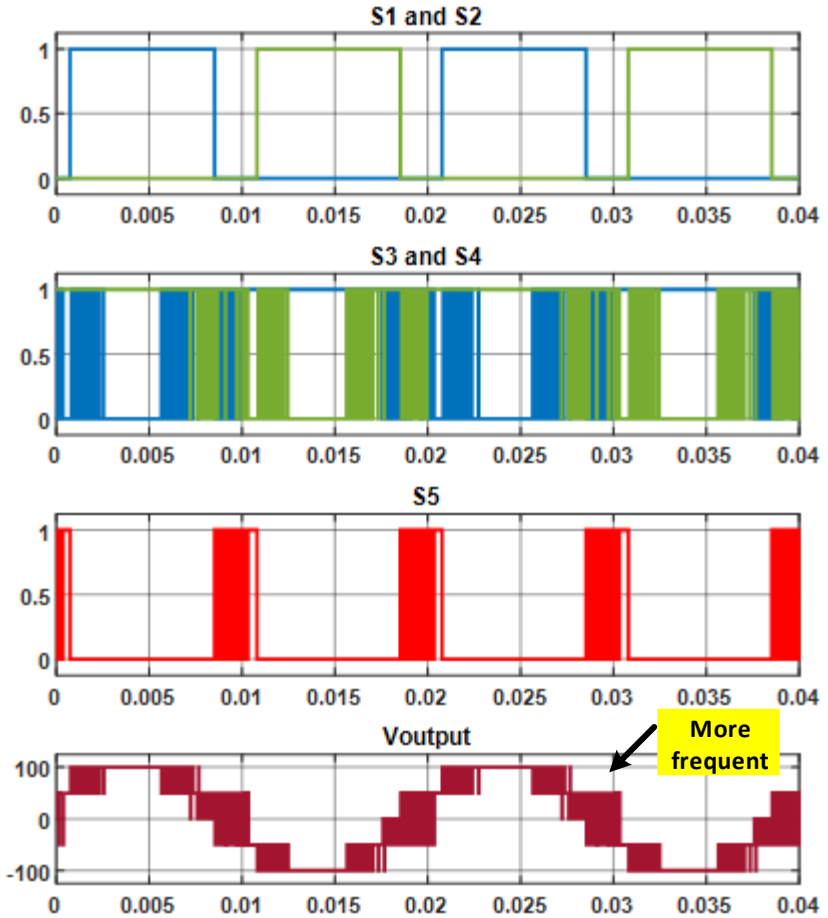

Fig. 7 Switching signals and output voltage at narrow-range hysteresis band

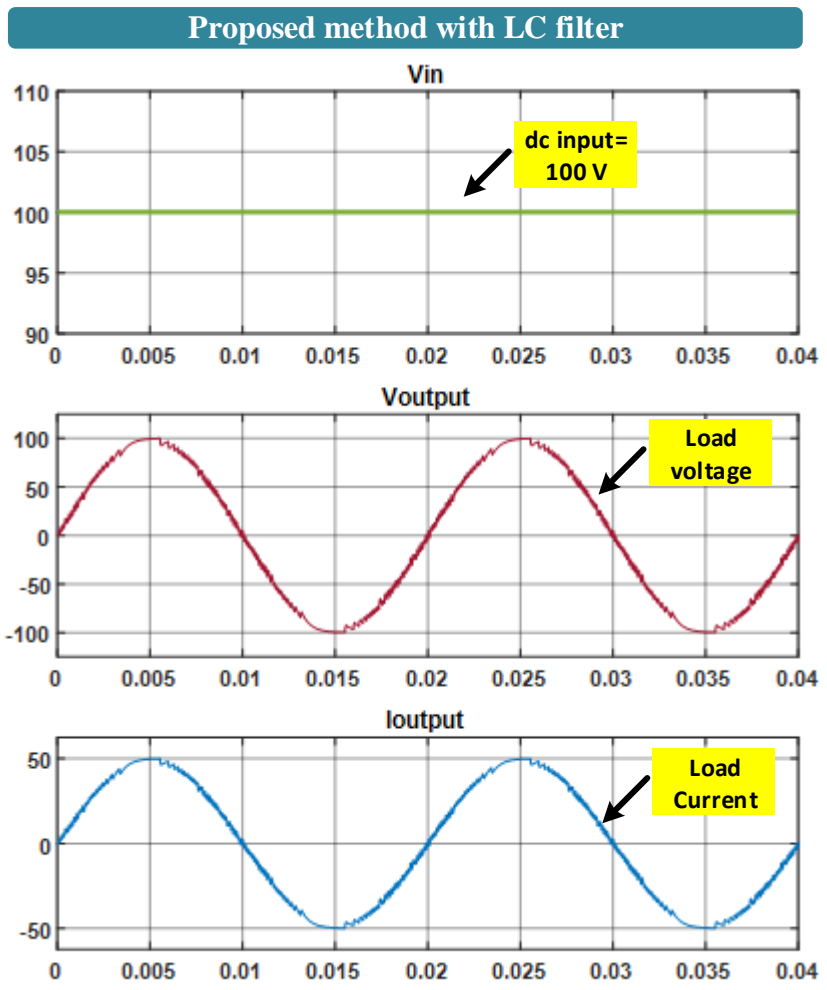

Fig. 8 The waveforms of filtered input/output voltages and output current under narrow hysteresis band control 


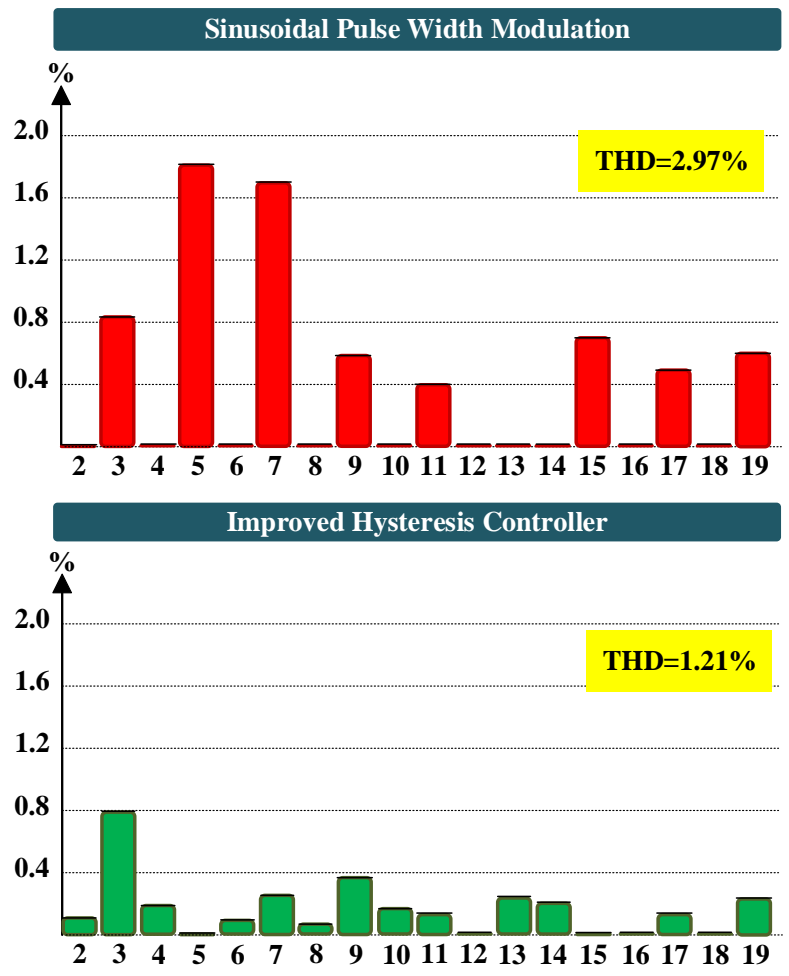

Fig. 9 THD comparison of conventional spwm and improved hysteresis controller at $10 \mathrm{kHz}$

Table III presents the THD value according to spwm and hysteresis methods. Also, the magnitudes of fundamental and individual harmonic components are given.

TABLE III THD VALUE, HARMONIC INDIVIDUAL PERCENTAGES AND PHASE DEGREES FOR SPWM AND HYSTERESIS METHODS

\begin{tabular}{ccccc}
\hline & \multicolumn{2}{c}{ Spwm } & \multicolumn{2}{c}{ Hysteresis } \\
\hline THD & $2.97 \%$ & & Percentage & Degree \\
\hline No & Percentage & Degree & 100 & -0.1 \\
\hline 1 & 100 & -0.8 & 0.22 & 117.4 \\
2 & 0.07 & 86.5 & 0.79 & 207.6 \\
3 & 0.85 & -37.4 & 0.35 & -27.1 \\
4 & 0.07 & 82.9 & 0.06 & 70.7 \\
5 & 1.83 & -17.2 & 0.17 & 248.9 \\
6 & 0.07 & 79.4 & 0.32 & 226.5 \\
7 & 1.72 & -10.8 & 0.15 & 60 \\
8 & 0.07 & 75.9 & 0.37 & 75.8 \\
9 & 0.54 & 9.4 & 0.21 & -83.2 \\
10 & 0.07 & 72.4 & 0.16 & 81.1 \\
11 & 0.40 & 16.3 & 0.06 & 205.6 \\
12 & 0.07 & 68.9 & 0.25 & -77.3 \\
13 & 0.04 & -69.6 & 0.21 & 18 \\
14 & 0.06 & 65.5 & 0.04 & -59.1 \\
15 & 0.70 & 198.6 & 0.15 & -68.3 \\
16 & 0.06 & 62.1 & 0.27 & -49.1 \\
17 & 0.51 & 268.7 & 0.06 & 159.6 \\
18 & 0.06 & 58.7 & 0.26 & 121.7 \\
19 & 0.62 & -45.1 & & \\
\hline
\end{tabular}

\section{CONCLUSION}

In this paper, hysteresis current controller is improved and adapted for five-level T-type inverter. In the proposed controller scheme, the main switches (S1, S2, S3 and S4) are triggered through hysteresis current controller modulation strategy. In order to generate these switching signals, the error signal between the actual load current and the reference signal is used as hysteresis input. The error signal and its inverted signals are compared with four hysteresis levels in order to generate switching signals of S1, S2, S3 and S4. In triggering of the bidirectional switch, the logical procedure is realized according to the truth table of T-type inverter. The proposed hysteresis controller with feedback current is tested and switching signals are generated for different hysteresis band values. According to the different hysteresis band values, it is obvious that the switching frequency changes in $\mathrm{kHz}$ levels. Also, the performance results of the proposed method are compared to conventional spwm technique implemented in Ttype inverter. The comparison results show that THD of hysteresis current controlled T-type inverter is lower than spwm controlled inverter. In this way, it presents that proposed modulation strategy shows excellent results for ac-dc voltage conversion in T-type inverter.

\section{REFERENCES}

[1] K. Zeb, W. Uddin, Muhammad A. Khan, Z. Ali, M. U. Ali, N. Christofides, et al., "A comprehensive review on inverter topologies and control strategies for grid connected photovoltaic system," Renewable and Sustainable Energy Reviews, vol. 94, pp. 1120-1141, 2018/10/01/ 2018.

[2] K. Matsui, Y. Kawata, and F. Ueda, "Application of parallel connected NPC-PWM inverters with multilevel modulation for AC motor drive," IEEE Transactions on Power Electronics, vol. 15, no. 5, pp. 901-907, 2000.

[3] A. Sinha, K. Chandra Jana, and M. Kumar Das, "An inclusive review on different multi-level inverter topologies, their modulation and control strategies for a grid connected photo-voltaic system," Solar Energy, vol. 170, pp. 633-657, 2018/08/01/ 2018.

[4] X. Guo and W. Chen, "Control of multiple power inverters for more electronics power systems: A review," CES Transactions on Electrical Machines and Systems, vol. 2, no. 3, pp. 255-263, 2018.

[5] M. S. Irfan, A. Ahmed, and J. Park, "Power-Decoupling of a Multiport Isolated Converter for an Electrolytic-Capacitorless Multilevel Inverter," IEEE Transactions on Power Electronics, vol. 33, no. 8, pp. 6656-6671, 2018.

[6] J. G. Subarnan, "4 - Multilevel inverters: an enabling technology," in Hybrid-Renewable Energy Systems in Microgrids, A. H. Fathima, N. Prabaharan, K. Palanisamy, A. Kalam, S. Mekhilef, and J. J. Justo, Eds. ed., Woodhead Publishing, 2018, pp. 61-80.

[7] K. Thakre, K. B. Mohanty, and A. Chatterjee, "Reduction of circuit devices in symmetrical voltage source multilevel inverter based on series connection of basic unit cells," Alexandria Engineering Journal, 2018/11/15/ 2018 .

[8] M. Ahmed, A. Sheir, and M. Orabi, "Asymmetric cascaded half-bridge multilevel inverter without polarity changer," Alexandria Engineering Journal, 2017/09/12/ 2017.

[9] E. Babaei, M. F. Kangarlu, M. Sabahi, and M. R. A. Pahlavani, "Cascaded multilevel inverter using sub-multilevel cells," Electric Power Systems Research, vol. 96, pp. 101-110, 2013/03/01/ 2013.

[10] Y. Suresh and A. K. Panda, "Investigation on stacked cascade multilevel inverter by employing single-phase transformers," Engineering Science and Technology, an International Journal, vol. 19, no. 2, pp. 894-903, 2016/06/01/ 2016.

[11] J. Jamaludin, S. Syamsuddin, N. A. Rahim, and H. W. Ping, "Control of switch-sharing-based multilevel inverter suitable for photovoltaic applications," Journal of the Franklin Institute, vol. 355, no. 3, pp. 1018-1039, 2018/02/01/ 2018.

[12] N. Prabaharan and K. Palanisamy, "Analysis and integration of multilevel inverter configuration with boost converters in a photovoltaic system," Energy Conversion and Management, vol. 128, pp. 327-342, 2016/11/15/ 2016.

[13] S. Mariethoz, "Systematic Design of High-Performance Hybrid Cascaded Multilevel Inverters With Active Voltage Balance and 
Minimum Switching Losses," IEEE Transactions on Power Electronics, vol. 28, no. 7, pp. 3100-3113, 2013.

[14] A. Ruderman, "About Voltage Total Harmonic Distortion for Singleand Three-Phase Multilevel Inverters," IEEE Transactions on Industrial Electronics, vol. 62, no. 3, pp. 1548-1551, 2015.

[15] A. Shukla, A. Ghosh, and A. Joshi, "State Feedback Control of Multilevel Inverters for DSTATCOM Applications," IEEE Transactions on Power Delivery, vol. 22, no. 4, pp. 2409-2418, 2007.

[16] J. Venkataramanaiah, Y. Suresh, and A. K. Panda, "A review on symmetric, asymmetric, hybrid and single DC sources based multilevel inverter topologies," Renewable and Sustainable Energy Reviews, vol. 76, pp. 788-812, 2017/09/01/ 2017.

[17] A. Chen and X. He, "Research on Hybrid-Clamped Multilevel-Inverter Topologies," IEEE Transactions on Industrial Electronics, vol. 53, no. 6, pp. 1898-1907, 2006.

[18] A. Narendrababu, N. Yalla, and P. Agarwal, "A modified T-type single phase five-level inverter with reduced switch voltage stress," 2018 International Conference on Power, Instrumentation, Control and Computing (PICC), 2018, pp. 1-5.

[19] K. Lee, H. Shin, and J. Choi, "Comparative analysis of power losses for 3-Level NPC and T-type inverter modules," 2015 IEEE International Telecommunications Energy Conference (INTELEC), 2015, pp. 1-6.

[20] M. M. Harin, V. Vanitha, and M. Jayakumar, "Comparison of PWM Techniques for a three level Modular Multilevel Inverter," Energy Procedia, vol. 117, pp. 666-673, 2017/06/01/ 2017.

[21] H. Athari, M. Niroomand, and M. Ataei, "Review and Classification of Control Systems in Grid-tied Inverters," Renewable and Sustainable Energy Reviews, vol. 72, pp. 1167-1176, 2017/05/01/ 2017.

[22] H. P. Vemuganti, D. Sreenivasarao, and G. S. Kumar, "Improved pulsewidth modulation scheme for T-type multilevel inverter," IET Power Electronics, vol. 10, no. 8, pp. 968-976, 2017.

[23] P. Singh, S. Tiwari, and K. K. Gupta, "A new topology of transistor clamped 5-level H-Bridge multilevel inverter with voltage boosting capacity," 2012 IEEE International Conference on Power Electronics, Drives and Energy Systems (PEDES), 2012, pp. 1-5.

[24] N. Abd Rahim, M. F. M. Elias, and W. P. Hew, "Transistor-Clamped H-Bridge Based Cascaded Multilevel Inverter With New Method of Capacitor Voltage Balancing," IEEE Transactions on Industrial Electronics, vol. 60, no. 8, pp. 2943-2956, Aug 2013.

[25] G. E. Valderrama, G. V. Guzman, E. I. Pool-Mazun, P. R. MartinezRodriguez, M. J. Lopez-Sanchez, and J. M. S. Zuniga, "A Single-Phase Asymmetrical T-Type Five-Level Transformerless PV Inverter," Ieee Journal of Emerging and Selected Topics in Power Electronics, vol. 6, no. 1, pp. 140-150, Mar 2018.

[26] M. Anzari, J. Meenakshi, and V. T. Sreedevi, "Simulation of a transistor clamped H-bridge multilevel inverter and its comparison with a conventional H-bridge multilevel inverter," 2014 International Conference on Circuits, Power and Computing Technologies [ICCPCT-2014], 2014, pp. 958-963.

[27] W. Huaisheng and X. Huifeng, "A Novel Double Hysteresis Current Control Method For Active Power Filter," Physics Procedia, vol. 24, pp. 572-579, 2012/01/01/ 2012.

[28] F. Wang, Y. Wang, L. J. Hang, and C. M. Wang, "Five-level inverter for solar system and its self-adaptive pulse-width modulation strategy," IET Power Electronics, vol. 9, no. 1, pp. 102-110, Jan 202016.

[29] L. Malesani, P. Mattavelli, and P. Tomasin, "Improved constantfrequency hysteresis current control of VSI inverters with simple feedforward bandwidth prediction," IEEE Transactions on Industry Applications, vol. 33, no. 5, pp. 1194-1202, 1997.

[30] D. S. Oh and M. J. Youn, "Automated adaptive hysteresis current control technique for a voltage-fed PWM inverter," Electronics Letters, vol. 26, no. 24, pp. 2044-2046, 1990.

[31] A. Fereidouni, M. A. S. Masoum, and K. M. Smedley, "Supervisory Nearly Constant Frequency Hysteresis Current Control for Active Power Filter Applications in Stationary Reference Frame," IEEE Power and Energy Technology Systems Journal, vol. 3, no. 1, pp. 1-12, 2016.

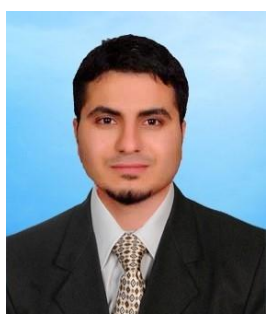

\section{BIOGRAPHIES}

MUSTAFA İNCi received the B.S. and M.S. degrees in Electrical-Electronics engineering from the Çukurova University, Adana, in 2011 and 2013 the Ph.D. degree in mechanical engineering from Çukurova University, Adana, Turkey, in 2017.

From 2011 to 2018, he was a Research Assistant with the Çukurova University. Since 2018, he has been an Assistant Professor with the Mechatronics Engineering Department, İskenderun Technical University. $\mathrm{He}$ is the author of more than 10 articles, and more than 20 conference papers. His research interests include grid integration of renewable energy systems and advanced power electronic converters. 